\title{
Preliminary Study on Readiness to Teach Online Due to Covid-19 Pandemic among University Academician in Malaysia
}

\author{
M. Amirul Mohamad Khairi, I. Faridah, H. Norsiah, and M. A. Ahmad Zaki
}

\begin{abstract}
The COVID-19 pandemic has prevented close engagement with students to avoid the spread of the virus. Hence, the transition from the traditional classroom methods to fully online teaching mode is essential. Academicians need to be equipped with the necessary devices and technical skills to conduct live video meetings (synchronous) and create recorded video (asynchronous). In this study, we have conducted a survey to assess the readiness of the academicians at the Center for Foundation Studies in Science, University of Malaya to teach online. 88 academicians participated in this study which consists of 68 local staff and 20 Japanese staff. The survey was conducted using Google Form, which focused on three main aspects of readiness. They were hardware readiness, software readiness and behavior (which include experiences, opinions, and expectation on online teaching). The results show that necessary equipment to conduct video meetings for lectures and tutorials such as webcam, microphone and should be provided. Continuous training should be provided to increase academicians' competencies in using the applications used. We hope that this research will provide some insights on the current condition that our academicians are having, what is the problem that they are facing and to plan ahead.
\end{abstract}

Index Terms-Online learning, online teaching, Covid-19, teaching and learning, pandemic.

\section{INTRODUCTION}

On the 30th January 2020, the World Health Organization (WHO) declared a Public Health Emergency of International Concern due to the Covid-19 outbreak. The outbreak which started from Wuhan, China has caused a major panic worldwide. The Covid-19 pandemic or also known as the coronavirus pandemic which is caused by severe acute respiratory syndrome coronavirus 2 (SARS-CoV-2). Millions of people lost their lives which resulted in WHO to declare it as a pandemic on 11th March 2020. The virus which is mainly spread between people in close proximity via small droplets produced by coughing, sneezing, and talking.

Manuscript received August 15, 2020; revised February 24, 2021. This work was supported in part by the Center of Foundation Studies in Science, University of Malaya, Malaysia.

M. Amirul Mohamad Khairi is witht the Mathematic Division of the Center of Foundation Studies in Science, University of Malaya, Malaysia. He is also with the Faculty of Education, University of Malaya, Malaysia (e-mail amirulkhairi@um.edu.my).

I. Faridah, H. Norsiah, and M. A. Ahmad Zaki are with the Mathematic Division of the Center of Foundation Studies in Science, University of Malaya, Malaysia (e-mail: faridah124@um.edu.my, norsiahashim@um.edu.my, azaki@um.edu.my).
The droplets usually fall to the ground or onto surfaces rather than travelling through air over long distances.

Due to this, the Government of Malaysia has declared a Movement Control Order (MCO) nationwide on 17th March 2020 to prevent the virus from spreading. Citizens have been ordered to stay at home and all outside activities must be stopped immediately. One of the sectors that is severely affected is the education system. Schools at all levels had to be closed to prevent any possible transmission. However, at the foundation studies level, the pandemic occurred at the end of the semester. Furthermore, this is the final semester for the students to complete their one-year program. The Center for Foundation Studies in Science, University of Malaya in Malaysia (CFS) has decided to continue with online learning. Any postponement will affect the intake for next first year undergraduate students in the month of September 2020 based on the normal academic calendar. Hence, throughout the period of 17th March 2020 until 3rd April 2020, all classes have been conducted online. This was a surprise for the academicians as they were not prepared for an Emergency Remote Teaching (ERT).

The same challenges also occurred throughout the world. In a paper by [1] reported their experience in implementing online learning at the University of the West Indies (UWI), Trinidad and Tobago, during the Covid-19 pandemic. They have shared the same experiences of struggle to adjust during the early stage of online teaching, the anxiety of the dangerous disease and program completion. They highlighted the needs for academicians to be more flexible, agile and adaptable to unforeseen events. In a paper by [2] discussed on the implementation of Emergency Remote Teaching (ERT) due to Covid-19 pandemic at the Middle East College, Oman. The most challenging part is time constraint. Curriculum transformation is anticipated to occur rapidly without sufficient preparation. On the perspective of the academicians, he argued that they should be equipped with the necessary tools, and must attain pedagogic creativity to engage the learned and stimulate them into learning. They also suggested that academicians should have the necessary technical skills to handle the applications and take advantage of the freely available resources online i.e. Youtube, FutureLearn and OpenLearn platforms.

After 3 months of isolation and work from home, the government has decided to re-open academic institutions by stages. At the university level, only certain groups of students are allowed to enter the University premises. This is part of the prevention measures to reduce the number of students in one place. The management of the university has decided to allow the new session of foundation studies at CFS to 
commence on the 26th June 2020. Students' registration and learning sessions will be conducted via online. In this study, we investigated the readiness of academicians for online teaching in the context of Covid-19 at the CFS. Prior to the Covid-19 pandemic, academicians at the CFS have conducted teaching and learning using blended teaching (traditional and online learning).

Three main software provided by the University of Malaya to facilitate online teaching are Spectrum (developed by University of Malaya), Google Suite and MS Teams (both subscribed by University of Malaya). However, the online learning part was only used to disseminate lecture notes, tutorial questions, assignment submission, quizzes and to record attendance. The major part of teaching which is verbal communication was conducted by traditional method of face to face. However due to the nature of how the virus is spread, traditional method of face to face is no longer allowed. This change of teaching mode gives a new challenge to the academicians. To adapt to this new method of teaching, academicians need to prepare themselves with the necessary skills. Table I describes the blended teaching that was used prior to Covid-19 and the proposed full online teaching to be implemented during this period.

\begin{tabular}{|c|c|c|c|c|}
\hline \multirow[b]{2}{*}{ Activities } & \multicolumn{2}{|c|}{ Blended Teaching } & \multicolumn{2}{|c|}{ Full Online Teaching } \\
\hline & Traditional & Online & Traditional & Online \\
\hline $\begin{array}{l}\text { Lecture by Face to } \\
\text { Face }\end{array}$ & Yes & No & No & Yes (MS Teams) \\
\hline $\begin{array}{l}\text { Tutorial by Face to } \\
\text { Face }\end{array}$ & Yes & No & No & Yes (MS Teams) \\
\hline Laboratory & Yes & No & No & Yes (MS Teams) \\
\hline Lecture Notes & No & $\begin{array}{c}\text { Yes } \\
\text { (Spectrum) }\end{array}$ & No & Yes (Spectrum) \\
\hline Tutorial Questions & No & $\begin{array}{c}\text { Yes } \\
\text { (Spectrum) }\end{array}$ & No & Yes (Spectrum) \\
\hline Quizzes & No & $\begin{array}{c}\text { Yes } \\
\text { (Spectrum) }\end{array}$ & No & Yes (Spectrum) \\
\hline Exam & Yes & No & No & Yes (Spectrum) \\
\hline $\begin{array}{l}\text { Assignment } \\
\text { Submission }\end{array}$ & Yes & $\begin{array}{c}\text { Yes } \\
\text { (Spectrum) }\end{array}$ & No & $\begin{array}{c}\text { Yes (Spectrum or MS } \\
\text { Teams) }\end{array}$ \\
\hline Record Attendance & Yes & $\begin{array}{c}\text { Yes } \\
\text { (Spectrum) }\end{array}$ & No & $\begin{array}{c}\text { Yes (Spectrum or MS } \\
\text { Teams) }\end{array}$ \\
\hline
\end{tabular}

In this study, our objective is to analyse the academicians' readiness in terms of hardware readiness (which include learning devices and internet), software readiness (which include applications that will be used for teaching) and behaviour (which include experiences, opinions and expectation on online teaching). The second objective is to give recommendations on how the academicians and management can prepare themselves. In order to achieve this, a survey is conducted to understand the current state of the academicians in CFS, and give recommendations on how the academicians and management can prepare themselves.

In the next section of the article, we will explain about the research methodology that has been taken. We will further explain the process of developing the instruments, how the survey was conducted and how the data was analysed. Then we will share the results from the data collected and discuss the findings. We end our report with conclusion and suggestions on the readiness of our academicians and what we should prepare in the future.

\section{ReseARCh Methodology}

The research design used in this study is an observational and descriptive survey method based on a questionnaire which focused on three main aspects of readiness. They were hardware readiness, software readiness and behavior towards online teaching amongst the academicians at the Center for Foundation Studies in Science, University of Malaya, Malaysia. The questionnaire was prepared in the form of Google docs and the link was sent to the staff through the email and mobile applications, that is WhatsApp. A total of 88 academicians participated in the study consisting of 68 local staff and 20 Japanese staff. They were from various departments such as Mathematics, Physics, Biology, Chemistry, Japanese and English. Out of 88 academicians who participated in the survey, there were 54 teachers $(61.4 \%)$ and 34 lecturers $(38.6 \%)$. Forty-seven of the academicians are females $(53.4 \%)$ while forty-one 41 are males $(46.6 \%)$.

The questionnaire designed for the staff consisted of 26 questions regarding the personal information, teaching devices, learning applications, experiences in e-learning and opinions, readiness and expectation. This questionnaire was then validated by 8 expert reviewers who were academicians from other universities. The validation was based on three empirical criteria created specifically for this study, and the reviewers evaluated the usefulness, relevance, and the quality of the items. The questionnaire was opened from 8th to 13th July 2020. The raw data which was obtained through the questionnaire were then analyzed using simple statistics analysis and the results were calculated.

\section{RESULTS}

\section{A. A. Demographic Study}

\section{1) Analysis of the number of years using traditional method of teaching}

In this study, 88 responses were obtained and it represents the opinions of $96 \%$ of the targeted audience. From the data collected, more than half of the academicians (62.5\%) who participated in the survey have more than 10 years' experience of traditional teaching methods. Then followed by 21 academicians $(23.9 \%)$ who have 5 to 10 years' experience. While 12 of the academicians (13.6\%) have less than 5 years' experience. These results are presented as in Fig. 1.

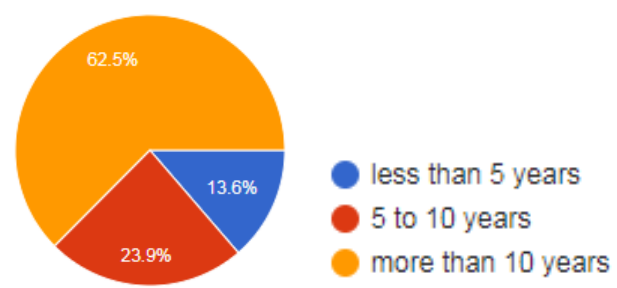

Fig. 1. The number of years using traditional teaching method (The traditional teaching method is referring to; face to face teaching in lecture hall or classroom)

2) Analysis on the number of years using online teaching method

About 60 academicians (68.2\%) reported that they do not have much experience in online teaching methods which are 
less than 2 years. Therefore, it seems that most of the academicians will expect to face some difficulties and have to struggle in handling the online teaching especially during the pandemic crisis. 21 academicians which is $23.9 \%$ have experienced teaching online between 2 to 5 years. While only 7 academicians $(8 \%)$ have more than 5 years of online teaching as shown in Fig. 2.

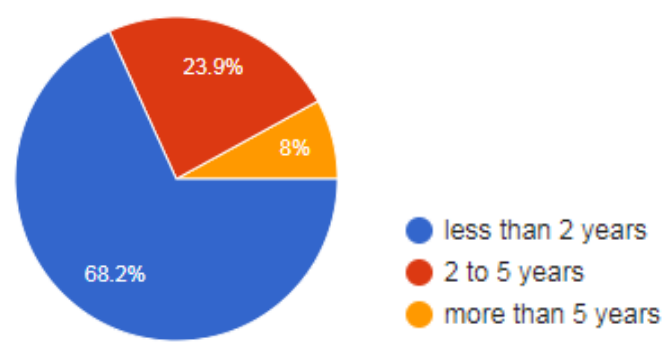

Fig. 2. The number of years using online teaching method (for example using Spectrum, Google Classroom, WhatsApp, etc).

\section{3) The devices provided by the institution for online teaching}

In this study, the devices for online teaching is one of the three main aspects to measure the readiness among the academicians. However, according to the survey, the institution only provides the basic devices for online teaching, such as desktop or laptop (see Table II). Most of the academicians, that is about $76.1 \%$ received desktop only. While 20 academicians that is $22.7 \%$ received a laptop. About $27.3 \%$ of academicians said that the institution provides printers. Less than $5 \%$ of the academicians claimed that the institution provides them tablets, mic, webcam and drawing board. (it is assumed that they are referring to their own devices). Thus, the lack of devices provided by the institution for online teaching is not a hindrance to continue the goal of an institution in providing quality education for the students.

\begin{tabular}{|c|c|c|}
\hline Devices & Number of Respondents & Percentage \\
\hline Desktop & 20 & $22.7 \%$ \\
\hline Laptop & 67 & $76.1 \%$ \\
\hline Tablet & 4 & $4.5 \%$ \\
\hline Smartphone & 14 & $15.9 \%$ \\
\hline Webcam & 3 & $3.4 \%$ \\
\hline Mic & 11 & $12.5 \%$ \\
\hline Drawing Board & 4 & $4.5 \%$ \\
\hline
\end{tabular}

\section{4) The devices required for online teaching}

The survey also covered the opinion from academicians on the required devices for online teaching. Therefore, it is found that most of the academicians think the following devices are important for online teaching: laptop, microphone, webcam and the drawing board. $79.5 \%$ of the academicians think that a laptop is required for their online teaching. While 61 out of $88(69.3 \%)$ academicians chose webcam as an important device for their teaching. $70.5 \%$ (62) of the respondents think that the microphone is also important. 49 of them think that a drawing board is a must for online teaching. Half of the respondents think that tablets are required for their online teaching. Other devices like printer and scanner also have been chosen by 40 and 36 of the academicians respectively as the required devices for online classes. These results are presented as in Fig. 3.

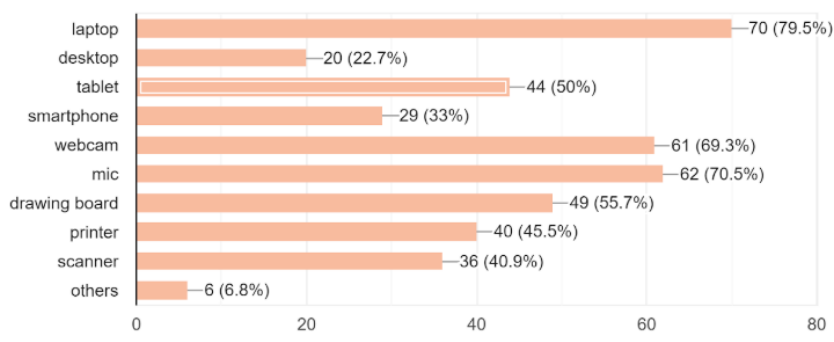

Fig. 3. The devices required for online teaching.

\section{5) Analysis on the internet accessibility}

Most of the academicians used UM Wi-Fi (the Wi-Fi provided by the institution) for their online teaching. Only 64 out of 88 respondents $(72.7 \%)$ use UM Wi-Fi as their internet access. $54(61.4 \%)$ of the academicians use UM LAN (Local Area Network). 51 (58\%) respondents use their own Personal Data to access the internet. These results (see Fig. 4) can be used to monitor the internet accessibility during the online teaching and can be served as a benchmark of the readiness among the academicians.

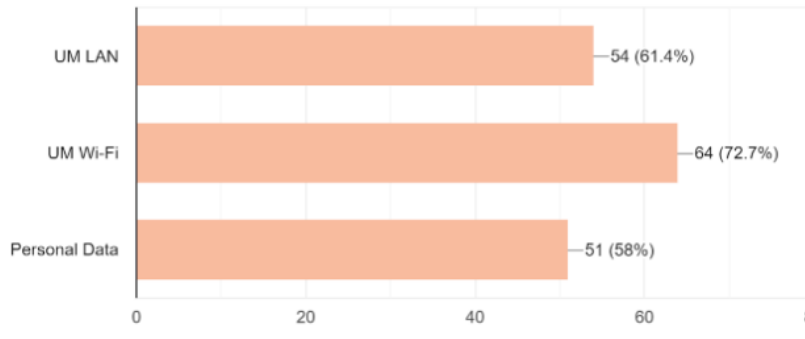

Fig. 4. The internet access among the academicians.

\section{6) Analysis on the internet connection stability}

The internet connection stability is crucial to ensure that institutions are able to cater the online teaching as well as to measure the hardware readiness among the academicians. According to the analysis, most of the academicians do not have any problems with their internet connection. $72.7 \%$ (64) of the respondents declared that their internet connection stability is good. $18.2 \%$ (16) of the academicians find the internet stability being very good. $8(9.1 \%)$ respondents claimed that their internet stability is poor. Fig. 5 represents these results.

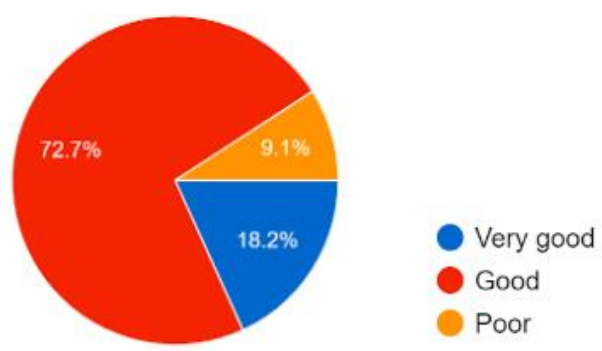

Fig. 5. The internet connection stability.

\section{B. Learning Applications for Online Teaching (Software)}




\section{1) The online teaching applications provided by the institution}

MS Teams (Microsoft Teams) and Spectrum is the most used application provided by the institution especially during the COVID-19 outbreak. Spectrum is an online application and it is the official platform for online teaching developed by the institution where academicians could upload their lecture notes and information for the students. Online quiz and assignment also can be done through Spectrum. Therefore, it is aligned with the result of the survey that indicates $88.6 \%$ of the respondents, that is about seventy-eight academicians claimed that the institution provides Spectrum for online teaching and learning. 87 out of 88 respondents, that is about $98.9 \%$ of them claimed that the institution provides MS Teams for online teaching and learning. About forty-six academicians (52.3\%) said that the institution also provides Google Suite. Other applications provided for online classes according to four (4.5\%) respondents are Zoom, Weber and Microsoft 365. Fig. 6 shows the above information.

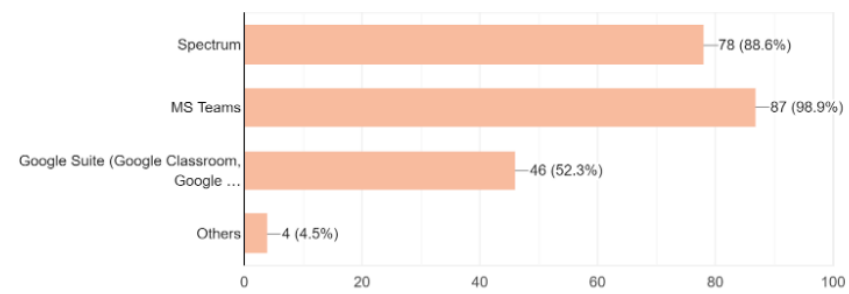

Fig. 6. The applications provided by the institution.

\section{2) The online teaching applications required by the academicians}

With regards to the readiness and preparation for teaching online, the majority of academicians reported that Ms Teams, Google Suite and Spectrum are the most required applications for online teaching. Precisely, 70 respondents (79.5\%) think that MS Teams are required for their online teaching. While 60 academicians (68.2\%) and 61 academicians $(69.3 \%)$ claimed that Spectrum and Google Suite respectively are required for their online teaching. Furthermore, about 43 respondents (48.9\%) think that Zoom is required for online teaching. These data can be interpreted as there are other applications favored by the academicians even though it is not provided by the institution. A few other required online teaching applications are Whatsapp, Telegram, Video editing Apps., SLACK, Mathematica, etc. Fig. 7 shows the overall percentages of these data.

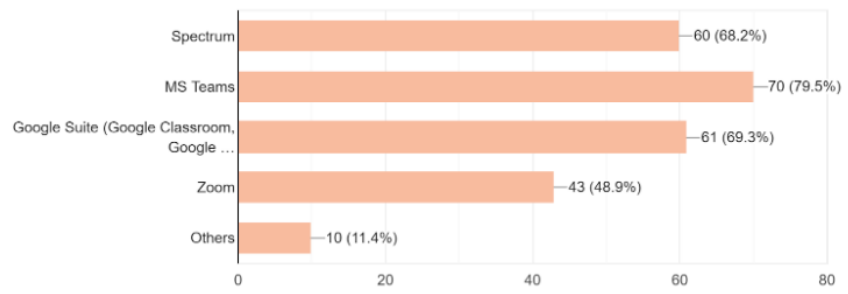

Fig. 7. The online teaching applications favored by the academicians.

Moreover, among other online teaching applications, 39 respondents reported that they also have used the following applications for their specific taught subjects, such as Grammarly, Japanese, Google Meet, GeoGebra, Microsoft
365, Flimoravideo, ChemDraw, Phet Simulation, Correct Speak and Procreate.

\section{Experiences in e-Learning (Behaviour)}

\section{1) Analysis on the perceptions towards spectrum}

The online teaching perceptions among the academicians towards the usage of Spectrum have also been treated in the survey according to their scale levels, see Fig. 8. Only 5.7\% of academicians strongly agree that Spectrum is easy to use. While $37.5 \%$ (or 33 staff) just agree that Spectrum is easy to use for online teaching. This is due to the lack of Spectrum which does not have the video features for online classes. However, three academic staff strongly disagree with this question. Fig. 8 presents the details of the survey output.

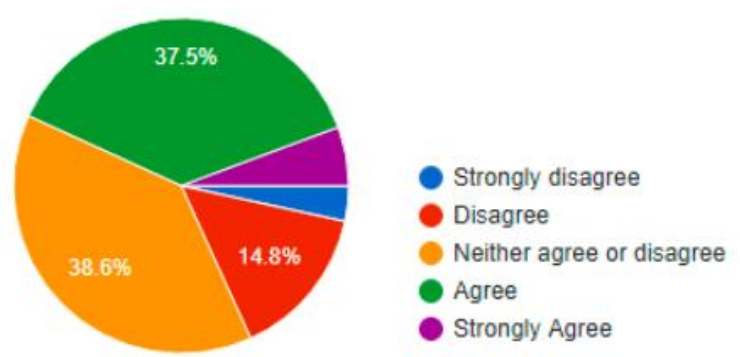

Fig. 8. Analysis whether Spectrum is easy to use.

\section{2) Analysis on the perceptions towards MS team}

The analysis on perceptions towards Ms Teams by academicians has been conducted within the five scales - strongly agree, agree, neither agree or disagree, disagree and strongly disagree - are reported in Fig. 9. Thus, there is a significant conclusion that can be made that $70.4 \%$ (or 62 respondents) agree MS Team is easy to use for online teaching and much easier compared to Spectrum.

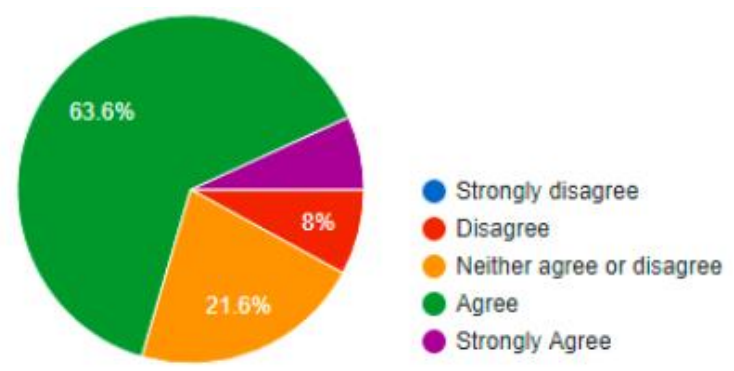

Fig. 9. Analysis whether MS Teams is easy to use.

3) Analysis on the perceptions towards conducting LIVE video lectures or tutorials

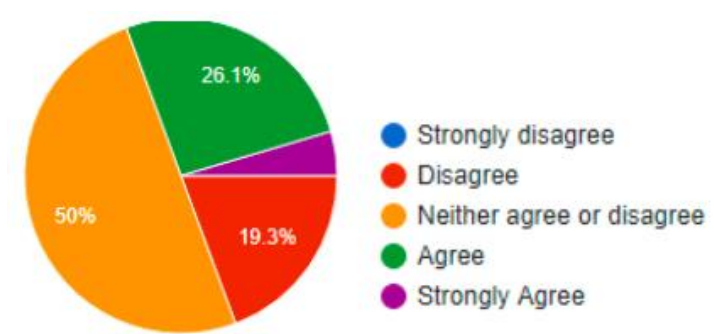

Fig. 10. Analysis whether conducting live video lectures are easy.

Although the implementation of the fully online teaching method is in ad-hoc, twenty-nine academicians (30.6\%) thought that conducting LIVE video lectures or tutorials are 
easy. Among these academicians, four of them strongly agreed to this question. However, half of the respondents were not confident whether conducting LIVE video lectures or tutorials would be easy or not. They neither agree nor disagree to this question. Seventeen staff members disagreed that conducting LIVE video lectures or tutorials are easy. However, none of the respondents strongly disagreed. These results are presented in Fig. 10.

4) Analysis on the perceptions towards creating videos for lectures or tutorials

$25.0 \%$ (or 22 staff) of the respondents agreed that it is easy to create videos for lectures or tutorials for online teaching. Among them three academicians (3.4\%) strongly agreed to this question. However, thirty respondents disagreed that creating videos for lectures was easy. This is about $34.1 \%$ of the respondents. Thirty-six academic members, which is about $40.9 \%$ of the respondents, neither agree nor disagree to this question. Probably they have not tried creating videos yet (See Fig. 11.)

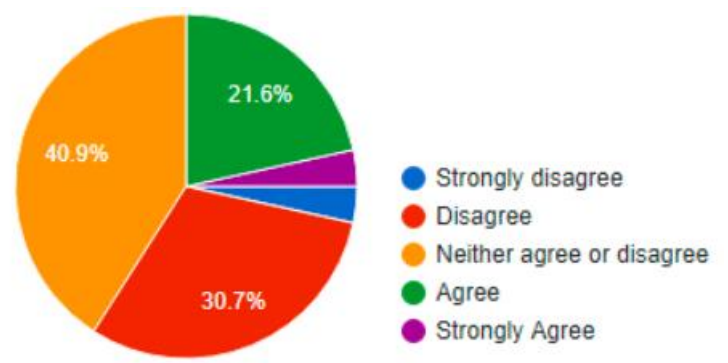

Fig. 11. Analysis whether it is easy to create video lectures for online teaching.

5) Analysis on the perceptions towards communicating with students through WhatsApp or any other social media

About $77.2 \%$ of the 88 respondents agreed that it is easy to use WhatsApp or other social media to communicate with students for online teaching. This is about 68 of the staff members. Only about seven academicians disagreed to this question. Thirteen academics were not very sure whether using WhatsApp or other social media, will ease the communication with students. They neither agree nor disagree to this question. Refer to Fig. 12 for the percentages obtained.

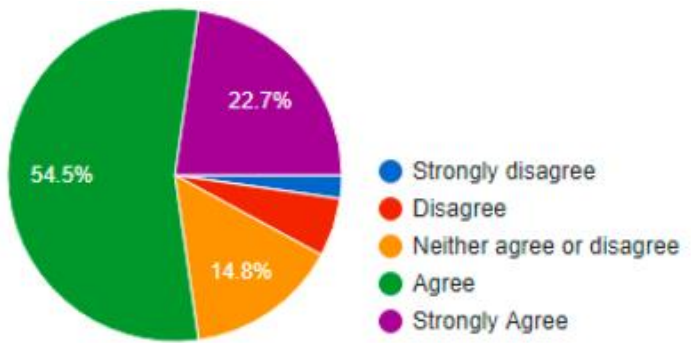

Fig. 12. Analysis on whether it is easy to communicate with students through WhatsApp or other social media.

6) Analysis on the perceptions towards engaging with the students during online teaching

About $23.8 \%$ (or 23 staff) agreed that it is easy to engage with the students during online teaching for online teaching. In fact, one staff strongly agreed to the question. Almost half of the respondents neither agree nor disagree with this question. Probably because they have not experienced online teaching before, Fig. 13 shows the output obtained. However, 30 academicians disagreed that it is easy to engage students during online teaching.

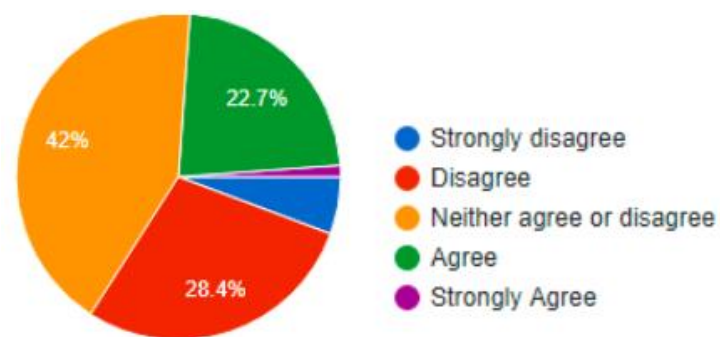

Fig. 13. Analysis on students' engagement during online teaching.

\section{7) Analysis on the spending hours for online teaching}

$45.5 \%$ of the academicians spend less than five hours per day on online teaching. Forty one out of eighty-eight staff spend between five to ten hours per day. Only 8 academicians spend more than 10 hours per day teaching online. We can conclude that $92.1 \%$ (or 81 staff). spend less than 10 hours a day for online teaching. Refer to Fig. 14 for this analysis of time spent for online teaching

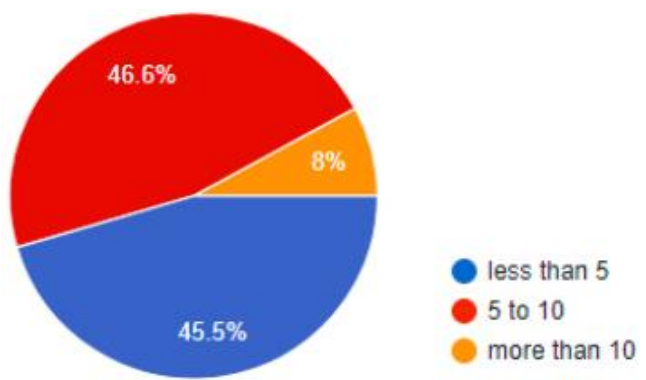

Fig. 14. Analysis on number of hours spent per day for online teaching

\section{8) Analysis on the experiences in online teaching}

For the analysis of the respondents' experience regarding online teaching, the following were some of the information shared by them.

1) To ensure the students understand our lecture, especially when it involves mechanisms or processes, we need to ask questions.

2) Students can still ask questions through chatting box but the lecturers may not be able to express the answers fully compared to the traditional method of teaching

3) Engagement with some students was poor.

4) Difficult to explain in detail to the students.

5) Live streaming for each class requires more of the students' internet data. So, some students may not be able to go LIVE for every class. Asynchronous is preferred although LIVE conferencing is also a must to engage students. Options should be given to students to perform synchronous or asynchronous learning.

6) Very difficult to edit laboratory video

7) I really enjoyed teaching online

8) It takes time to learn to teach online

9) Students staying in rural areas have poor internet connection

10)Unstable internet connections 


\section{Opinion, Readiness and Expectation}

\section{1) Analysis on the readiness to teach lectures or tutorials online}

In this section, readiness is the key phrase for the analysis particularly on conducting lectures and tutorials online. Thus, from the analysis, it is found that more than half of the staff $(56.8 \%)$, which is about 50 academicians, agreed that they are ready to teach lectures or tutorials online. About 30 others were not very sure whether they were ready or not to teach online. Eight other academicians were not confident enough to teach online. Fig. 15 shows the output obtained from the questionnaire.

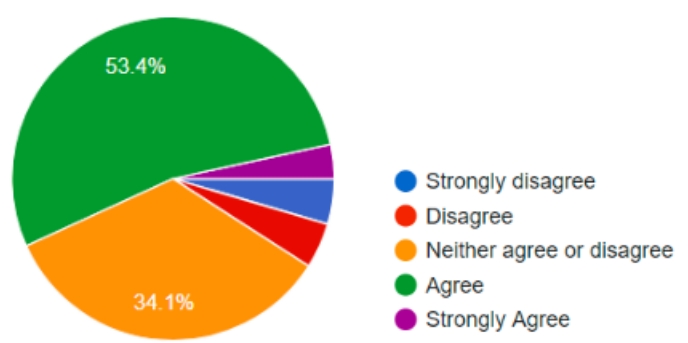

Fig. 15. Analysis whether the academicians were ready to teach online.

\section{2) Analysis on the perceptions towards the students'} readiness in online learning

Regarding the analysis on the perceptions among the academicians whether the students are ready to learn online, $54.5 \%$ of the respondents, which is about 48 staff members neither agree nor disagree to the question. It shows that half of them cannot predict the readiness of the new students for online learning. Only one staff member strongly agreed that the students are ready for online teaching. Twenty academic members also agreed to this question. About three academicians strongly disagreed that students are ready for online teaching and 16 staff (18.2\%) disagreed to this question. Only $23.8 \%$ of the respondents feel that the students are ready to learn online. Fig. 16 below shows the data obtained.

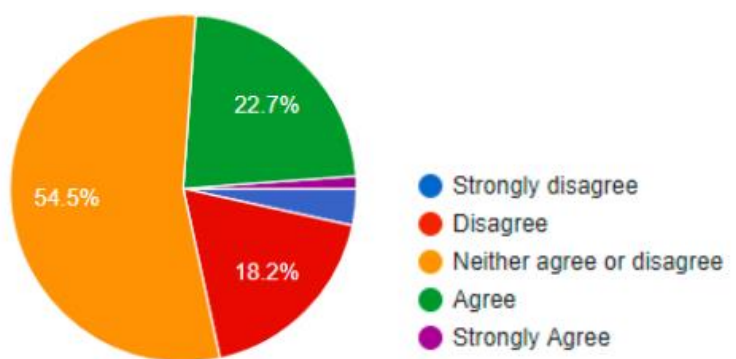

Fig. 16. Analysis on whether the students are thought to be ready to learn online.

\section{3) Analysis on the perceptions towards online teaching}

For the analysis on the respondents' opinion regarding online teaching, less than $50 \%$ agreed with the positive items suggested. The overall results showed that the academicians have difficulties in online teaching. Only fifteen academicians agree that online teaching is efficient and effective. This is only $17 \%$ of the respondents. $36.4 \%$ of the respondents thought that online teaching would save time. 15 respondents also claimed that online teaching applications are easy to use. $30.7 \%$ of the respondents thought that online teaching would save energy and twenty-two academicians claimed that teaching online would save cost. Apart from these, some academicians thought that online teaching will be very boring unless one knows how to attract students to focus and listen to the online lectures. Respondents also thought that online teaching is not efficient and takes time in getting used to it. Some of them thought that it would be more effective if the internet connection was good. academicians also claimed that teaching online is time consuming because a lot of preparation is to be done before conducting each class. Some of the respondents thought that a lot of time is used for the preparation of online teaching. (see Fig. 17)

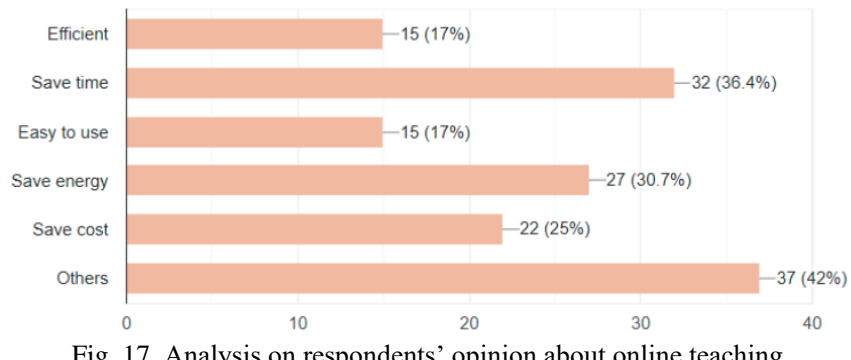

Fig. 17. Analysis on respondents' opinion about online teaching.

\section{4) Analysis on the expectations towards the online teaching process}

The final analysis is on the respondents' expectation about the online teaching process at the Center for Foundation Studies in Science University of Malaya. The academicians felt that online classes are not suitable for science practical and tutorials. Some respondents also expected that online teaching should be more flexible and blended with conventional teaching. A number of academicians hoped that online learning should be the official medium for teaching and learning for the institution. Some thought that it should be done gradually and would run smoothly if the internet connection is good. Others hoped that online teaching would complement the traditional method of teaching.

\section{DISCUSSION}

Based on previous briefings from the data obtained, $79.5 \%$ of the academicians believe that a laptop is required for their online teaching. laptop, microphone, web cam, drawing board. One of the important components in mobile learning is laptops. There are many types of laptops in the market such as Acer, Asus, Compaq, Apple models and many more. However, each laptop needs to be replaced every two or three years by ensuring adequate capacity and equipped with the use of the latest technology. The configuration for each model should be identified in advance as the configuration changes all the time and the laptop also support wireless technology [3].

The teaching and learning process nowadays is no longer concentrated in the classroom alone, instead it can happen anywhere and anytime. The education system has undergone another evolution in educational technology when mobile learning or Mobile Learning (M-Learning) was introduced to improve the level of teaching and learning by [4].

The implementation of M-Learning at CFS is still in the early stage. M-Learning is a new concept implemented in the 
learning process. It emphasizes on the ability to facilitate the learning process without being tied to the physical location of the learning process taking place [5].

Our results showed that $62.5 \%$ of the academicians in CFS were used to apply traditional teaching method and $68.2 \%$ of the academicians in CFS does not have much experience in online teaching method (less than 2 years). [6] suggested that simulation-based online when combined with good pedagogical approaches, appropriate technology and educational technology, and the presence of experts will provide a better experience in simulations. Simulations could be a very motivating tool for e-learning classrooms. [7] mentioned that because computer technology and the internet are both boundless even a small boy has already been equipped with a device or a cell phone. It's no surprise that new innovations have been part of the cycle of teaching and learning Reyes-Chua (2020).

Online learning and teaching at the university is very important because [8] even though the campuses have been closed, the academicians are working hard. They are available via online for students in daily basis to reduce the hardship among the students across the country due to the COVID-19 pandemic.

In this study, we concluded that $23.8 \%$ agreed that it is easy to engage with the students during online teaching for online teaching. We also found that $43.2 \%$ agreed that MS team and Spectrum is easy to use for online teaching. MS Teams and Spectrum is the most used application provided by the institution. Less than half of academicians have used a specific application for their subjects.

Overall synchronous and asynchronous learning modes adoption were considered. Synchronous learning is a well-structured learning strategy, where the courses are scheduled at specific times on virtual classroom settings which were carried out through MS Teams and Spectrum. These two applications are the most used application provided by the institution, whereas involving chemistry and biology subjects using laboratories learning, the courses are not scheduled on live virtual classroom settings. Apart from scheduled class time, discussion also conducted via social networking tool (WhatsApp software and more) [2]. From the data collected, we also found that $92.1 \%$ spend less than 10 hours a day for online teaching, $23.8 \%$ agreed that it is easy to engage with the students during online teaching for online teaching, $77.2 \%$ agree easy to use WhatsApp or other social media to communicate with students for online teaching, $25.0 \%$ agreed that it is easy to create videos for lectures or tutorials for online teaching [9].

\section{CONCLUSION}

Our findings showed that the academicians are not necessary equipment to conduct teaching online. Basic equipment such as a webcam and microphone are not provided. Necessary equipment based on the needs of subjects should also be provided to facilitate the teaching process, for example drawing boards with a digital pen. The university provides three online platforms for online learning. Spectrum is developed by UM and must be used by the academicians while Google and MS Teams are third party providers subscribed by the University. The main drawback of Spectrum is that video meeting features are not available. Hence academicians need to use Google Meet or MS Teams to support this feature. This also contributes to difficulty among academicians as they have to switch between Spectrum and Google Meet or MS Teams. To avoid confusion among students, the academicians have agreed to use MS Teams for all video meetings with students. Therefore, there is a need to study the efficiency of the methods used (ie SPECTRUM and MS Teams throughout the first semester). Beside that, each subject should identify suitable applications that can be used to facilitate and engage students [10]. [2] also suggested that academicians should take the freely available resources in the internet to make online learning more interesting and stimulating.

The urgency of changing to online teaching mode has caused anxiety among academicians as they need to acquire a new set of skills immediately. Motivations and training on how to use them should be provided to the academicians to keep interested in teaching online. The University must provide workshops to teach academicians on how to use SPECTRUM and MS Teams effectively. Continuous technical support is very important to ensure that every academician is fully trained. This research only covers the aspect of readiness among academicians in terms of hardware, software and behavior. A more comprehensive study on readiness that involves all stakeholders should be conducted. In the paper by [11], they have studied the e-learning situation before and after 3 weeks of implementation at the Graz University of Technology, Austria during the Covid-19 pandemic. They have found that the e-learning readiness framework by [12] was very helpful in describing and assessing the readiness of their university. They suggested that the framework can be further improved with further questions on how do the general conditions change the quality of teaching, the study ability of the subjects and also the learning outcomes of the students? and to what extent do the experiences of teachers and students change future behavior with regard to e-learning?

In the paper [8], they have investigated the students' perspective, attitude and readiness about online classes at the Graphic Era Hill University, India. They found that students enjoy online learning because of the flexibility of time and place. However, they are dissatisfied with lack of curricular activities. This is because the Movement Control Order (MCO) does not allow any close proximity activities. The same study should be conducted on the students as well. We hope that this study will continue to fill in all the gaps and give a broader view on the preparations that should be taken in the future if there's an emergency. Whether the whole online learning system should online be a contingency plan or be continued in normal session when it is allowed.

\section{CONFLICT OF INTEREST}

The authors declare no conflict of interest.

\section{AUTHOR CONTRIBUTIONS}

M. Amirul Mohamad Khairi was the research leader and responsible for planning and execution for each research 
stage. The research team includes I. Faridah, H. Norsiah and M.A.Ahmad Zaki. Together we have conducted the research from the instrument development, validity, reliability, run survey and analyze the data. The paper was written together by sections. All authors had approved the final version.

\section{ACKNOWLEDGMENT}

We would like to thank you to the management and all academic members of the Center of Foundation Studies, University of Malaya for the support given throughout this study.

\section{REFERENCES}

[1] R. C. Kalloo, B. Mitchell, and V. J. Kamalodeen, "Responding to the COVID-19 pandemic in Trinidad and Tobago: Challenges and opportunities for teacher education," Journal of Education for Teaching, 2020, p. 1-1.

[2] A. O. Mohmmed, B. A. Khidhir, A. Nazeer, and V. J. Vijayan, "Emergency remote teaching during Coronavirus pandemic: The current trend and future directive at Middle East College Oman," Innovative Infrastructure Solutions, 2020, vol. 5, no. 3.

[3] R. A. Rahman and M. H. Mohd Hashim, M-Pembelajaran dalam Pendidikan Teknik dan Vokasional (PTV) di Malaysia, 2011.

[4] A. R. N. Penggunaan, "Mobile learning (m-learning) untuk tujuan pembelajaran dalam kalangan pelajar kejuruteraan UTHM," Doctoral dissertation, Universiti Tun Hussein Onn Malaysia.

[5] A. Kukulska-Hulme and J. Traxler, Mobile Learning: A Handbook for Educators and Trainers, Psychology Press; 2005.

[6] R. McHaney, L. Reiter, and I. Reychav, "Immersive simulation in constructivist-based classroom e-learning, International Journal on E-Learning, 2018, vol. 17, no. 1, pp. 39-64.

[7] B. R. Tulaev et al., Developing competencies in the development of information and communication technologies," Journal of Critical Reviews. 2019, vol. 7, no. 2.

[8] S. Lall and N. Singh, "CoVid-19: Unmasking the new face of education," International Journal of Research in Pharmaceutical Sciences, 2020, vol. 11, pp. 48-53.

[9] E. Sela and Y. Sivan, "Enterprise e-learning success factors: An analysis of practitioners' perspective (with a downturn addendum)," Interdisciplinary Journal of E-Learning and Learning Objects, 2009, vol. 5, no. 1, pp. 335-43.

[10] A. Hamdan, R. Din, and S. Z. Manaf, "Penerimaan m-pembelajaran dalam sistem pendidikan di Malaysia melalui the unified theory of acceptance and use of technology (UTAUT): Satu analisis literature," in Proc. 1st International Conference on Mobile Learning, Applications, and Services (mobilcase2012), 2013, vol. 1, no. 2, pp. 93-97.

[11] M. Ebner et al., "COVID-19 epidemic as e-learning boost? Chronological development and effects at an Austrian University against the background of the concept of 'e-learning readiness'," Future Internet, 2020, vol. 12, no. 6, p. 94.

[12] A. A. Alshaher, "The McKinsey 7S model framework for e-learning system readiness assessment," International Journal of Advances in Engineering \& Technology, 2013, vol. 6, no. 5.

Copyright $\odot 2021$ by the authors. This is an open access article distributed under the Creative Commons Attribution License which permits unrestricted use, distribution, and reproduction in any medium, provided the original work is properly cited (CC BY 4.0).

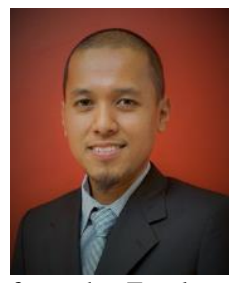

M. Amirul Mohamad Khairi currently an education officer at the Mathematics Division of the Center for Foundation Studies in Science, University of Malaya in Malaysia. He has taught mathematics subjects such as calculus, algebra, vector and statistics for more than 10 years. He also teaches the subject of computer programming.

He received his first degree in electrical engineering from the Faculty of Engineering, University of Malaya in 2005. After graduating he worked as an electronic engineer for 3 years. In 2013, he completed his masters in computer science study from Faculty of Computer Science, University of Malaya. In 2017, he completed his postgraduate diploma in education at the Faculty of Education in University of Malaya. Currently, besides working as an education officer, he is also a doctoral candidate at the Faculty of Education, University of Malaya. His main interest is in mathematics in education, e-learning, mobile learning and STEM.

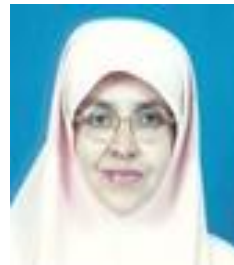

I. Faridah was born in Ipoh, Perak, Malaysia. She obtained her first degree (1991) in pure mathematics from the Science University of Malaysia. She continued her masters (1999) and $\mathrm{PhD}$ (2008) in educational mathematics in University of Malaya. Her major field of study is e-learning, m-learning, rasch model evaluation, educational studies and STEM education.

She is a senior lecturer at the Centre for Foundation Studies in Science, University of Malaya. She has published a book namely, Algebra and Calculus Q \& A, Kuala Lumpur, Pearson, 2012. Faridah has also published a chapter in book, Exploring Sixth-Form Students interest in Stem Education in The Best Practices in STEM Mentor Mentee (pp 87 - 99), Kuala Lumpur, University of Malaya Publication, 2019. She also has published papers in ISI-indexed journals, namely Using Rasch Model to analyse the ability of pre-University students in Vector, Kuala Lumpur, 2015.

She is the programme coordinator for Applied Science and Islam at University of Malaya since 2016. She is a member of ICT/e-learning, STEM education (University level), and National Science and Mathematics Society (National level)。

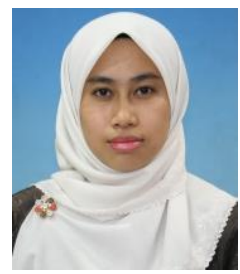

H. Norsiah is a senior lecturer in the mathematics section at CFS, University of Malaya (UM), Kuala Lumpur. She holds BSc and MSc degrees in industrial mathematics and applied mathematics respectively from University Technology of Malaysia, Johor. In 2013 she completed her PhD in the field of applied mathematics in astrophysics.

She worked for 15 years as a mathematics lecturer and 10 years as a researcher at Radio Cosmology Research Laboratory Group, Physics Department, Faculty of Science, UM. As part of the research group, she was involved with the dark matter study specifically on the rotation curve and MOND (Modified Newtonian Dynamic) analysis. Her other research interests include the oscillatory problems with perturbation methods and nonlinear fitting models.

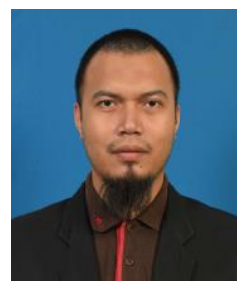

M. A. Ahmad Zaki is a teacher in the mathematics division at Center for Foundation Studies in Science, University of Malaya (UM), Kuala Lumpur. He holds a BSc in computer science, MSc in applied mathematics respectively and in 2018 he completed her $\mathrm{PhD}$ in the field of applied mathematics from University Technology of Malaysia, Johor. He worked for 10 years as a mathematics lecturer. 